\title{
Root production and quality attributes of sweetpotato genotypes in Brasília-DF, Brazil, during two cropping seasons
}

Raphael Augusto de Castro e Melo, Geovani Bernardo Amaro, Giovani Olegário da Silva, Francisco Herbeth Costa dos Santos, Larissa Pereira de Castro Vendrame

Embrapa Hortaliças, Brasília, DF.. E-mail: raphael.melo@embrapa.br

\section{Resumo}

O conhecimento da adaptação de genótipos de batata-doce a ambientes e da eficiência de seu processo de produção em diversos sistemas de cultivo são essenciais para que genótipos com melhor desempenho sejam conhecidos. Assim, objetivou-se avaliar genótipos de batata-doce quanto à produção de raízes e atributos de qualidade em duas épocas Brasília-DF, Brasil. Avaliou-se nove genótipos de batata-doce: BRS Amélia, Beauregard, Brazlândia Branca, Brazlândia Rosada, Brazlândia Roxa, BRS Cuia, Princesa, BRS Rubissol e um genótipo local em delineamento de blocos casualizados, com quatro repetições. Estimou-se características relacionadas a produção de raízes, características de qualidade e danos causador por insetos. $\mathrm{O}$ genótipo Brazlândia Rosada se destacou em relação a produção de raízes $\left(66,03 \mathrm{t}\right.$ ha ${ }^{-1}$ e $31,58 \mathrm{t}$ $\mathrm{ha}^{-1}$ para o primeiro e o segundo experimentos, respectivamente) e também apresentou um bom índice de formato de raízes $(2,00)$. Não há grande variabilidade genética entre os genótipos para o índice de danos por insetos, sendo que BRS Amelia e BRS Cuia possuem características de formato menos desejáveis. Nenhuma variabilidade genética foi encontrada entre os genótipos referente a danos causados por insetos. Os genótipos BRS Amélia e BRS Cuia apresentaram o índice de formato de raízes menos desejado. Nas condições deste estudo, em relação aos caracteres avaliados, o genótipo Brazlândia Rosada apresentou resultados superiores em termos de produção de raízes e índice de forma.

Palavras-chave: Ipomoea batatas (L.) Lam; produtividade; danos por insetos; índice de formato de raízes.

Produção e atributos de qualidade de raízes de genótipos de batata-doce em Brasília-DF, Brasil, durante duas safras

\begin{abstract}
The understanding of the adaptation of sweet potato genotypes to environments and the efficiency of its production process in diverse growing systems are essential for best performance genotypes to be known. Thus, the aim of this study was to evaluate sweet potato genotypes for root production and quality attributes in two cropping seasons in Brasília-DF, Brazil. Nine genotypesn were evaluated: BRS Amélia, Beauregard, Brazlândia Branca, Brazlândia Rosada, Brazlândia Roxa, BRS Cuia, Princesa, BRS Rubissol and a local control were grown in a complete randomized blocks design with four replications. Characteristics related to root yield, quality and pest( insects) damage were evaluated. The genotype Brazlândia Rosada stands out in relation to root yield $\left(66.03 \mathrm{t} \mathrm{ha}^{-1}\right.$ and $31.58 \mathrm{t} \mathrm{ha}^{-1}$ for first and second experiments, respectively) and also presented a good root shape index (2.00). There is no great genetic variability among genotypes for insect damage index, with genotypes BRS Amelia and BRS Cuia preseting less desirable shape characteristics. No genetic variability was found among genotypes for insect damage. Genotypes BRS Amélia and BRS Cuia presented the least desired root shape index. Under the conditions of this study regarding the characters evaluated, genotype Brazlândia Rosada presented superior results in terms of roots production and shape index.
\end{abstract}

Keywords: Ipomoea batatas (L.) Lam; yield; insect damage; root shape index. 


\section{Introduction}

Sweetpotato [Ipomoea batatas L. (Lam.)] is among the world's most important, versatile and underexploited food crops, with a production of 112.8 million tons (Mt) (FAOSTAT 2018). Playing an important role in the developing countries, Brazil harvested 741.203 thousand metric tons $(\mathrm{Kt})$ in an area of 53.024 thousand hectares (Kha) with an average yield of $13.998 \mathrm{t}$ ha $^{-1}$ in 2018 (IBGE, 2019).

Although twenty-nine (29) genotypes are registered in the Brazilian Ministry of Agriculture, Livestock and Food Supply (BRASIL, 2019), most farmers grow unimproved genotypes, commonly adopted without a previous evaluation, that tend to result in low yields, presenting inferior characteristics that are not desired by the local market. Moreover, these genotypes cannot express their full genetic potential due to continuous propagation of the same planting material, leading to systematic accumulation of diseases and degeneration, mainly with viruses, in addition to conditions of low fertility soils and inadequate production systems (FERNANDES 2013; CARMONA et al. 2015; SILVA et al. 2015; AMARO et al. 2017; AMARO et al. 2019).

Selected genotypes adapted to a specific environment condition and to different growing systems are essential, in addition to the use of technologies that can improve the effectiveness of production processes. Thus, besides the correct management of planting material and use of healthy slips/vines, and high yield genotypes that are resistant to insect damages, roots with an appearance suited to market demands are also necessary (AZEVEDO et al. 2014; MASSAROTO et al. 2014; SILVA et al. 2015). These genotypes can reach values of yield superior to $30 \mathrm{t} \mathrm{ha}^{-1}$ in cycles of crop growing of four to five months (ANDRADE JÚNIOR et al. 2009; ANDRADE JÚNIOR et al. 2012; AMARO et al. 2019).

In this perspective, the present work aimed to evaluate root production and quality attributes of sweetpotato genotypes in BrasíliaDF, Brazil in a commercial field area located in Núcleo Rural Tabatinga, Brasília-DF, Brazil, in two subsequent cropping seasons.

\section{Material and Methods}

Two experiments were conducted in subsequent years in a commercial production area located at Núcleo Rural Tabatinga, BrasiliaDF, Brazil, (1545'36.62"S and 47³5'12.12" W). The first experiment was conducted from
December 18, 2013 to May 28, 2014 and the second experiment was conducted from December 10, 2014 to June 10, 2015. Soil was classified as a Typic Haplustox (Distrophic Red Latosol), showing the following chemical proprieties: $\mathrm{pH}\left(\mathrm{H}_{2} \mathrm{O}\right)=5,9 ; \mathrm{H}^{+++} \mathrm{Al}^{+++}=1,8 \mathrm{cmolc}$ $\mathrm{dm}^{3} ; \mathrm{Ca}^{++}=6,2 \mathrm{cmolc} \mathrm{dm}^{-3} ; \mathrm{Mg}^{++}=2,9 \mathrm{cmolc} \mathrm{dm}^{-3}$; $\mathrm{P}($ Mehlich $)=62,1 \mathrm{mg} \mathrm{dm}^{-3} ; \mathrm{K}^{+}=0,164 \mathrm{cmolc} \mathrm{dm}^{-3}$; Organic matter $=46,6 \mathrm{~g} \mathrm{dm}^{-3}$. To stablish both experiments, $600 \mathrm{~kg} \mathrm{ha}^{-1}$ of 04-30-16 fertilizer were banded preplant and a posterior sprinkler irrigation schedule followed a weekly application of $20 \mathrm{~mm}$, during the days without rainfall. Means of accumulated rainfall were collected by an automatic local weather station, with values of $1050 \mathrm{~mm}$ and $1180 \mathrm{~mm}$ for first and second experiment, respectively. After plowing and disking the soil to set bed rows $0.6 \mathrm{~m}$ apart, slips/vines were transplanted $0.4 \mathrm{~m}$ apart, at a depth of 3 inches with 4 plant nodes bared in the soil, leaving 3 leaves and nodes above the ground. Weed control was realized 21 days after transplantation (DAT) manually.

After 150 days, for both experiments, roots were harvested and evaluated for total root number (TRN); commercial root number (CRN); total root mass (TRM) in $\mathrm{t} \mathrm{ha}^{-1}$; commercial root mass (CRM) in $\mathrm{t} \mathrm{ha}{ }^{-1}$; average commercial root mass $(A C R M)=$ ratio between $C F M$ and $C R N$ and the percentage of $C R N$ in relation to TRN (\%CRN/TRN). Roots mass were weighted by an electronic scale and the ones considered commercially suited presented $\geq 10 \mathrm{~cm}$ length and $\geq 5 \mathrm{~cm}$ diameter, with no tortuosity, cracks or prominent veins (Silva et al., 2012). Roots shape (SI) and insect damage (ID) indexes were evaluated on a scale of 1 to 5 according to Peixoto et al. (1999) and Azevedo et al. (2014). For insects damage (ID), visual scores correspond to 1 - free of insect damage; 2 - few damages; 3 - damages that harm commercial aspects; 4 damages that make most roots aspects unsuited to commercialization; 5 - damages that make all roots unacceptable to commercialization. For shape index, visual scores corresponded to 1 regular fusiform without veins or cracks; 2 slightly disuniform with the presence of veins; 3 disuniform, with large veins and cracks; 4 - very disuniform, with the presence of large veins and cracks; 5 - out of commercial standards, with very irregular shape, large veins and cracks (MASSAROTO et al., 2014).

A complete randomized blocks design with four replications was used to evaluate eight 
Embrapa sweet potato genotypes (BRS Amélia, Beauregard, Brazlândia Branca, Brazlândia Rosada, Brazlândia Roxa, BRS Cuia, Princesa, BRS Rubissol) and a local variety used as control. Indexed planting material (vines/slips) was multiplied in a greenhouse and the process of virus elimination and testing followed the methods described by Fernandes (2013). Plots were formed by 24 plants.

Data were tested for normal distribution by Lilliefors test and submitted to analysis of individual and combined variance for the two periods of experiments, and cluster means were compared by Scott-Knott grouping test at $5 \%$. All statistical analyses were performed using GENES software (CRUZ, 2006).

\section{Results and Discussion}

The analysis of variance showed that there was an interaction between genotypes and experiments periods for total root number and commercial root mass. Thus, the results were discussed separately for both periods 2013/2014 and 2014/2015 (Table 1). For commercial root mass (CRM), the percentage of CRN in relation to TRN (\%CRN/ TRN), roots shape index (SI) and insect damage (ID) there was no interaction and the results are presented with the average means for both experiments periods (Table 2).

Table 1. Grouping of nine sweet potato genotypes phenotypic characters. Núcleo Rural Tabatinga BrasíliaDF.

\begin{tabular}{|c|c|c|c|c|}
\hline \multicolumn{5}{|c|}{ First experiment (2013/2014) } \\
\hline Genotypes & TRN & TRM $\left(\mathrm{t} \mathrm{ha}^{-1}\right)$ & CRN & CRM $\left(\mathrm{t} \mathrm{ha}^{-1}\right)$ \\
\hline Beauregard & $128.50 \mathrm{a}$ & $23.10 \mathrm{~b}$ & $55.50 \mathrm{~b}$ & $14.78 \mathrm{c}$ \\
\hline Brazlândia Branca & $147.50 \mathrm{a}$ & $39.20 \mathrm{~b}$ & $74.25 b$ & $28.59 \mathrm{~b}$ \\
\hline Brazlândia Rosada & $133.25 \mathrm{a}$ & $66.03 \mathrm{a}$ & 99.75 a & 60.70 a \\
\hline Brazlândia Roxa & $146.25 \mathrm{a}$ & $46.65 b$ & $84.25 \mathrm{a}$ & $35.55 \mathrm{~b}$ \\
\hline BRS Amélia & $105.25 \mathrm{a}$ & $31.56 \mathrm{~b}$ & $54.00 \mathrm{~b}$ & $24.88 \mathrm{~b}$ \\
\hline BRS Cuia & $104.75 \mathrm{a}$ & $36.67 \mathrm{~b}$ & $60.50 \mathrm{~b}$ & $28.63 \mathrm{~b}$ \\
\hline BRS Rubissol & $119.50 \mathrm{a}$ & $27.32 b$ & $53.50 \mathrm{~b}$ & $16.63 c$ \\
\hline Princesa & $105.50 \mathrm{a}$ & $36.73 \mathrm{~b}$ & $66.25 \mathrm{~b}$ & $30.78 \mathrm{~b}$ \\
\hline Local variety - control & $117.50 \mathrm{a}$ & $31.51 \mathrm{~b}$ & $66.75 b$ & $25.33 \mathrm{~b}$ \\
\hline Means & 123.11 & 37.64 & 68.30 & 29.54 \\
\hline CV\% & 20.72 & 23.90 & 19.83 & 28.00 \\
\hline GCV/PCV & 0.43 & 1.32 & 1.03 & 1.54 \\
\hline \multicolumn{5}{|c|}{ Second experiment (2014/2015) } \\
\hline Genotypes & TRN & TRM $\left(\mathrm{t} \mathrm{ha}^{-1}\right)$ & CRN & CRM $\left(\mathrm{t} \mathrm{ha}^{-1}\right)$ \\
\hline Beauregard & $197.25 \mathrm{~b}$ & $18.85 \mathrm{~b}$ & $60.50 \mathrm{~b}$ & $11.33 \mathrm{~b}$ \\
\hline Brazlândia Branca & $180.50 \mathrm{~b}$ & $24.12 b$ & $67.75 b$ & $16.41 \mathrm{~b}$ \\
\hline Brazlândia Rosada & $118.75 \mathrm{c}$ & $31.58 \mathrm{a}$ & $70.50 \mathrm{~b}$ & 27.83 a \\
\hline Brazlândia Roxa & $241.00 \mathrm{a}$ & $34.80 \mathrm{a}$ & 109.75 a & $26.14 \mathrm{a}$ \\
\hline BRS Amélia & $161.25 \mathrm{c}$ & $28.84 \mathrm{a}$ & $66.50 \mathrm{~b}$ & $21.68 \mathrm{a}$ \\
\hline BRS Cuia & $126.00 \mathrm{c}$ & $29.07 \mathrm{a}$ & $71.50 \mathrm{~b}$ & $24.81 \mathrm{a}$ \\
\hline BRS Rubissol & $190.50 \mathrm{~b}$ & $22.01 \mathrm{~b}$ & $55.25 \mathrm{~b}$ & $12.96 \mathrm{~b}$ \\
\hline Princesa & $150.00 \mathrm{c}$ & $28.94 \mathrm{a}$ & $78.50 \mathrm{~b}$ & $24.02 \mathrm{a}$ \\
\hline Local variety - control & $131.00 \mathrm{c}$ & $21.78 \mathrm{~b}$ & $66.50 \mathrm{~b}$ & $16.25 b$ \\
\hline Means & 166.25 & 26.66 & 71.86 & 20.16 \\
\hline CV\% & 16.40 & 22.30 & 21.09 & 27.19 \\
\hline $\mathrm{CVg} / \mathrm{CV}$ & 1.37 & 0.72 & 0.90 & 0.98 \\
\hline
\end{tabular}

TRN = total number of roots per plot; TRM = total mass of roots $\left(t^{~ h a}{ }^{-1}\right)$ per plot; $C R N=$ commercial root number, meaning roots $\geq 10 \mathrm{~cm}$ length and $\geq 5 \mathrm{~cm}$ diameter, with no tortuosity, cracks or prominent veins; CRM = commercial root mass $\left(\mathrm{t} \mathrm{ha}{ }^{-1}\right) . \mathrm{CV}(\%)=$ phenotypic coefficient of variation; $\mathrm{CVg} / \mathrm{CV}=$ ratio between the genotypic and phenotipic coefcient of variation. Means followed by the same letter in the column do not differ using the least significant difference values of $\leq 0.5 \%$ by Scott-Knott grouping test. 
Table 2. Grouping of nine sweet potato genotypes phenotypic characters. Núcleo Rural Tabatinga. BrasíliaDF.

\begin{tabular}{lllll}
\hline Genotypes & ACRM & \%CRN/TRN & SI & ID \\
\hline Beauregard & $176.84 \mathrm{c}$ & $61.98 \mathrm{~d}$ & $1.63 \mathrm{~b}$ & $1.63 \mathrm{a}$ \\
Brazlândia Branca & $244.19 \mathrm{c}$ & $69.57 \mathrm{c}$ & $1.88 \mathrm{~b}$ & $1.75 \mathrm{a}$ \\
Brazlândia Rosada & $384.72 \mathrm{a}$ & $89.70 \mathrm{a}$ & $2.00 \mathrm{~b}$ & $1.75 \mathrm{a}$ \\
Brazlândia Roxa & $257.64 \mathrm{c}$ & $75.11 \mathrm{~b}$ & $1.50 \mathrm{~b}$ & $1.25 \mathrm{a}$ \\
BRS Amélia & $295.04 \mathrm{~b}$ & $75.32 \mathrm{~b}$ & $3.25 \mathrm{a}$ & $2.00 \mathrm{a}$ \\
BRS Cuia & $318.28 \mathrm{~b}$ & $82.28 \mathrm{a}$ & $3.00 \mathrm{a}$ & $1.75 \mathrm{a}$ \\
BRS Rubissol & $208.72 \mathrm{c}$ & $59.60 \mathrm{~d}$ & $1.88 \mathrm{~b}$ & $1.75 \mathrm{a}$ \\
Princesa & $296.25 \mathrm{~b}$ & $83.31 \mathrm{a}$ & $1.75 \mathrm{~b}$ & $1.50 \mathrm{a}$ \\
Variedade local & $237.00 \mathrm{c}$ & $77.45 \mathrm{~b}$ & $1.75 \mathrm{~b}$ & $1.38 \mathrm{a}$ \\
\hline Means & 268.74 & 74.92 & 2.07 & 1.64 \\
CV\% & 16.17 & 8.13 & 30.36 & 23.11 \\
CVg/CV & 1.39 & 1.58 & 0.92 & 0.49 \\
\hline
\end{tabular}

$\mathrm{ID}=$ insect damage scores from $1=$ free of insect damage; $2=$ little damage; $3=$ damage that impair the commercial aspect; $4=$ practically unsuitable for the market; $5=$ completely unsuitable for commercial purposes. ACRM $=$ average commercial root mass ratio between CRM and \%CRN/TRN = percentage of CRN in relation to TRN. CV (\%) = phenotypic coefficient of variation; $\mathrm{CVg} / \mathrm{CV}=$ ratio between the genotypic and phenotipic coefcient of variation. Means followed by the same letter in the column do not differ using the least significant difference values of $\leq 0.5 \%$ by ScottKnott grouping test.

Significant differences were found between genotypes for most variables, by means of $F$ test at $5 \%$ of probability ( $p<0.05$ ), except for total root number (TRN) in the first experiment (Table 1) and insect damage (ID) for both experiments periods (Table 2). For characters related to root production, the coefficient of variation $(\mathrm{CV})$ presented a significant interaction for genotype $\mathrm{x}$ growing periods, ranging from $16.40 \%$ for TRN to $28 \%$ CRM (Table 1). For all other traits, coefcient of variation (CV) was $16.17 \%$ for ACRM and $8.13 \%$ for \%CRN/TRN. Visual scores indexes SI and ID presented values of $30.36 \%$ and $23.11 \%$, respectively.

The CV values for sweetpotato phenotypic roots characters in this work showed similar results to the ones found in the literature (BARRETO et al. 2011; ANDRADE JÚNIOR et al. 201; SILVA et al. 2012; AZEVEDO et al. 2014; MASSAROTO et al. 2014; CARMONA et al. 2015; SILVA et al. 2015; AMARO et al. 2017; AMARO et al. 2019). This confirms the information that these traits possess a quantitative inheritance that is strongly influenced by the environment (SILVA et al. 2015). Regarding the visual index evaluated using scores, Carmona et al. (2015) in their work presented values of $19.28 \%$ for $\mathrm{SI}$ and 9.05\% for ID, showing a better experimental accuracy. As well, Andrade Junior et al. (2012) indicated values of $10.30 \%$ for $\mathrm{SI}$ and $8.50 \%$ for ID. Additionally, Azevedo et al. (2014) work shown average values of $19.43 \%$ for $\mathrm{SI}$ and $20.39 \%$ for ID. The aforementioned results indicate that these two traits, especially $\mathrm{SI}$, need to be evaluated warily due to their smaller degree of accuracy.

The relation between the genotypic coefficient of variation (GCV) and phenotypic coefficient of variation $(\mathrm{PCV})=(\mathrm{GCV} / \mathrm{PCV})$ was superior to 0.90 for most traits, indicating the importance of genetic variability in comparison to total variation. This proportion was smaller for TRM in 2015 (0.72), mostly due to characters with no significant differences among genotypes (Table 1 and 2). Regarding the CRM means, both periods of the experiments showed values between $20.16 \mathrm{t} \mathrm{ha}^{-1}$ to $29.54 \mathrm{t} \mathrm{ha}^{-1}$, outyielding the national and regional averages of $13.24 \mathrm{t} \mathrm{ha}^{-1}$ and $14.5 \mathrm{t} \mathrm{ha}^{-1}$, respectively (EMATER-DF 2017; IBGE, 2019). Genotype Brazlândia Rosada, particularly, achieved $60.70 \mathrm{t} \mathrm{ha}^{-1}$ in 2014, 1.67 times greater than highest yield average of the Center West region of Brazil with $36.28 \mathrm{t} \mathrm{ha}^{-1}$ (IBGE, 2019).

The same genotype also showed a superior TRM value in the first experiment, achieving $66.03 \mathrm{t} \mathrm{ha}^{-1}$ in, and a TRN of 118.75 in the second experiment period. As well an ACRM value of $384.72 \mathrm{~g}$ and \%CRN/ TRN relation value (89.70\%) - Tables 1 and 2. Brazlândia Roxa presented a high number of roots, both commercial and total (Table 1), although that 
didn't reflect in a larger root mass, probably due to roots of reduced size. For $\mathrm{SI}$, considering roots with regular fusiform form without veins or cracks, genotypes BRS Amélia and BRS Cuia presented higher scores, meaning that their roots were considered less desirable (Table 2). Genotypes BRS Amélia, BRS Cuia, BRS Rubissol, Brazlândia Roxa e Beauregard, also using indexed planting material, were evaluated by Silva et al. (2015), obtaining values ranging from $22.43 \mathrm{t} \mathrm{ha}^{-1}$ to $32.34 \mathrm{t} \mathrm{ha}^{-1}$ for commercial root mass, harvested at 150 DAT, a comparable result to the persent work.

The ACRM values here obtained, with $268.74 \mathrm{~g}$ of roots, are also adequate to commercial standards that suggests values between $200 \mathrm{~g}$ and $400 \mathrm{~g}$, according to Miranda (1989). Azevedo et al. (2000) reported an average mass of roots ranging from $123.3 \mathrm{~g}$ to $261.4 \mathrm{~g}$ in a six-month cycle. Resende (2000), in a 200 days cycle, observed values ranging from 387.2 to 381,0 g evaluating genotypes Brazlândia Roxa and Princesa, respectively. Andrade Junior et al. (2009), in a seven months cycle, obtained values ranging from $182.94 \mathrm{~g}$ to $320.95 \mathrm{~g}$, and $199,14 \mathrm{~g}$ e 233,84 g for genotypes Princesa and Brazlândia Roxa, respectively. Silva et al. (2015) achieved means of $455 \mathrm{~g}$. In the present work ACRM values are within that range for most genotypes, except for Beauregard that produced commercial roots averaging $176.84 \mathrm{~g}$.

It wasn't possible to observe differences among genotypes for ID, by reason of a smaller genetic variance presented by this character. Even though a reduced numeric value was obtained for genotype Brazlândia Roxa (1.25), and this genotype being mentioned as a resistant (RESENDE, 1999). Azevedo et al. (2014) evaluated genotypes Brazlândia Rosada and Princesa and also classified them with a good resistance level, especially the genotype Princesa. Peixoto et al. (1999) affirmed that Brazlândia Branca and Brazlândia Rosada were susceptible. Barreto et al. (2011) considered Brazlândia Branca susceptible, meanwhile Brazlândia Rosada and Brazlândia Roxa were resistant. Massaroto et al. (2014) also considered the genotype Brazlândia Roxa as the most resistant.

\section{Conclusions}

No notable genetic variability was found among genotypes for insect damage. Genotypes BRS Amélia and BRS Cuia presented the least desired root shape index. As results, under the conditions of this study regarding the characters evaluated, genotype Brazlândia Rosada presented superior results in terms of roots production and shape index.

\section{References}

AMARO, G. B.; TALAMINI, V.; FERNANDES, F. R.; SILVA, G. O.; MADEIRA, N. R. Desempenho de cultivares de batata-doce para rendimento e qualidade de raízes em Sergipe. Revista Brasileira de Ciências Agrárias, v. 14, n. 1, p. 1-6, 2019. ttps://doi.org/10.5039/agraria.v14i1a5628

AMARO, G. B.; FERNANDES, F. R.; SILVA, G. O.; MELLO, A. F. S.; CASTRO, L. S. Desempenho de cultivares de batata doce na região do Alto Paranaíba-MG. Horticultura Brasileira, v. 35, n. 2, p. 286-291, 2017. https://doi.org/10.1590/s0102$\underline{053620170221}$

ANDRADE JUNIOR, V. C.; VIANA, D. J. S.; FERNANDES, J. S. C.; FIGUEIREDO, J . A.; NUNES, U. R.; NEIVA, I. P. Selection of sweet potato clones for the region Alto Vale do Jequitinhonha. Horticultura Brasileira, v. 27, n. 3, p. 389-393, $2009 . \quad$ https://doi.org/10.1590/S0102$\underline{05362009000300024}$

ANDRADE JUNIOR, V. C.; VIANA, D. J. S.; PINTO, N. A. V. D.; RIBEIRO, K. G.; PEREIRA, R. C.; NEIVA, I. P.; AZEVEDO, A. M.; ANDRADE, C. R. Características produtivas e qualitativas de ramas e raízes de batata-doce. Horticultura Brasileira, v. 30, n. 4, p. 584-589, 2012.

https://doi.org/10.1590/s0102$\underline{05362012000400004}$

AZEVEDO, A. M.; ANDRADE JUNIOR, V. C.; VIANA, D. J. S.; ELSAYED, A. Y. A. M.; PEDROSA, C. E.; NEIVA, I. P.; FIGUEIREDO, J . A. Influence of harvest time and cultivation sites on the productivity and quality of sweet potato. Horticultura Brasileira, v. 32, n. 1, p. 21-27, 2014. https://doi.org/10.1590/S010205362014000100004

AZEVEDO, A. M; FREITAS J. A.; MALUF, W. R.; SILVEIRA, M. A. Desempenho de clones e métodos de plantio de batata-doce. Acta Scientiarum, v. 22, n. 4, p. 901-905. 2000.

BARRETO, H. G.; SANTOS L. B DOS; OLIVEIRA G. I. S DE.; SANTOS G. R DO; FIDELIS R. R.; SILVEIRA M. A.; NASCIMENTO I. R. Estabilidade e 
adaptabilidade da produtividade e da reação a insetos de solo em genótipos experimentais e comerciais de batata-doce. Bioscience Journal, v. 27, n. 5, p. 739-747. 2011.

BRASIL. Ministério da Agricultura, Pecuária e Abastecimento. Registro Nacional de Cultivares. Brasília: RNC, 2019. Disponível em: http://extranet.agricultura.gov.br/php/snpc/gen otypeweb/cultivares registradas.php. Acesso em: 10 set. 2019.

CARMONA P. A. O.; PEIXOTO J. R.; AMARO G. B.; MENDONÇA, M. A. Divergência genética entre acessos de batata-doce utilizando descritores morfoagronômicos das raízes. Horticultura Brasileira, v. 33, n. 2, p. 241-250, 2015.

https://doi.org/10.1590/S0102-

$\underline{053620150000200017}$

CRUZ, C. D. Programa genes: biometria. Viçosa: UFV, 2006. 382 p.

EMPRESA DE ASSISTÊNCIA TÉCNICA E EXTENSÃO RURAL (EMATER-DF). Custos de produção. Brasília: EMATER, 2017. Disponível em: http://www.emater.df.gov.br/custos-deproducao/. Acesso em: 07 jan. 2018.

FAOSTAT. Countries by commodity: sweet potatoes. EUA: FAO, 2018. Disponível em: http://www.fao.org/faostat/en/\#rankings/countr ies by commodity. Acesso em: 11 maio 2018.

FERNANDES, F. R. Limpeza clonal de batata-doce: produção de matrizes com elevada qualidade fitossanitária. Brasília, DF: Embrapa Hortaliças, 2013. 8 p. (Embrapa Hortaliças. Circular técnica, 117).

INSTITUTO BRASILEIRO DE GEOGRAFIA E ESTATÍSTICA (IBGE). Produção agrícola municipal: 2019. Brasília: SIDRA, 2019. Disponível em: https://sidra.ibge.gov.br/pesquisa/pam/tabelas.

Acesso em: 25 out. 2019.

MASSAROTO J. A.; MALUF W. R.; GOMES L. A. A.; FRANCO H. D.; GASPARINO C. F. Desempenho de clones de batata-doce. Ambiência, v. 10, n. 1, p. 73-81. 2014.

https://doi.org/10.5935/ambiencia.2014.01.06

MIRANDA J. E. C. Brazlândia Roxa; Brazlândia Branca; Brazlândia Rosada e Coquinho: novas cultivares de batata-doce. Horticultura Brasileira, v. 7, n. 1, p. 32-33, 1989.

PEIXOTO J. R.; SANTOS L.C; RODRIGUES F. A; JULIATTI F. C; LYRA J. R. M. Seleção de clones de batata-doce resistentes a insetos de solo. Pesquisa Agropecuária Brasileira, v. 34, n. 3, p. 385-389, 1999. https://doi.org/10.1590/S0100$\underline{\text { 204X1999000300009 }}$

RESENDE, G. M. Características produtivas de cultivares de batata-doce sob condições irrigadas e de sequeiro na região norte de Minas Gerais. Horticultura Brasileira, v. 17, n. 2, p. 151-154, $1999 . \quad$ https://doi.org/10.1590/S0102$\underline{05361999000200015}$

RESENDE, G. M. Características produtivas de cultivares de batata-doce em duas épocas de colheita, em Porteirinha - MG. Horticultura Brasileira, v. 18, n. 1, p. 68-71, 2000.

https://doi.org/10.1590/S0102-

$\underline{05362000000100016}$

SILVA G. O.; PONIJALEKI R.; SUINAGA F. A. SILVA, G. O; PONIJALEKI, R.; SUINAGA, F. A. Divergência genética entre acessos de batata-doce utilizando caracteres fenotípicos de raiz. Horticultura Brasileira, v. 30, n. 4, p. 595-599, 2012.

https://doi.org/10.1590/S010205362012000400006

SILVA G. O.; SUINAGA F. A.; PONIJALEKI, R.; AMARO, G. B. 2015. Desempenho de cultivares de batata-doce para caracteres relacionados com o rendimento de raiz. Ceres, v. 62, n. 4, p. 379383, Aug. 2015. https://doi.org/10.1590/0034737X201562040007 